\title{
Identification and Characterization of a Novel Efficient Resistance Response to the Furoviruses SBWMV and SBCMV in Barley
}

\author{
Rebecca Lyons, Kim E. Hammond-Kosack, and Kostya Kanyuka \\ Centre for Sustainable Pest and Disease Management, Department of Plant Pathology and Microbiology, \\ Rothamsted Research, Harpenden, Hertfordshire, AL5 2JQ, United Kingdom
}

Submitted 20 March 2008. Accepted 24 April 2008.

\begin{abstract}
The interaction between the furoviruses Soilborne cereal mosaic virus (SBCMV) and Soilborne wheat mosaic virus (SBWMV) and their main host wheat is well documented; however, to date, only a few reports have addressed the response of other cereal species to these viruses. Here, we show that, in contrast to wheat, barley germplasm is a rich source of resistance to furoviruses. Moreover, we demonstrate that barley genotypes respond differentially to SBCMV and SBWMV, thereby providing an additional biological basis for classification of these viruses as two separate species. Following natural (soil) inoculation, some barley genotypes permitted foliar infection by SBWMV, whereas all 22 genotypes tested were resistant to SBCMV. Resistance is unlikely to be directed toward the virus vector, because Polymyxa graminis DNA was detected in the roots of all tested genotypes. Resistance to SBCMV in some barley genotypes was overcome by artificial virus inoculation onto the leaves, suggesting a block on virus translocation from roots to shoots as in resistant wheat genotypes. However, other genotypes were fully resistant following both inoculation techniques. One barley genotype, 'Dayton,' exhibited extreme resistance to both furoviruses. Further molecular analyses suggested that this novel and highly efficient resistance to furoviruses in barley operates by limiting virus spread from the primary inoculated cells.
\end{abstract}

Additional keywords: plasmodiophorid, tissue-print immunoassays (TPIA), translocation resistance.

Soilborne wheat mosaic virus (SBWMV) and Soilborne cereal mosaic virus (SBCMV) are causal agents of the soilborne mosaic disease of cereal crops. SBWMV was first identified in Illinois in 1919 (McKinney 1937), and has since been reported from the Americas, Canada, Japan, New Zealand, and Africa (Brakke and Landenberg 1988; Gill 2004; Kapooria et al. 2000). Intriguingly, this virus has also been detected in single fields in Germany (Koenig and Huth 2003) and France (Hariri and Meyer 2007). In contrast to SBWMV, SBCMV appears to be limited to Europe (Clover et al. 1999; Jezewska 1995; Koenig and Huth 2000a). SBWMV and SBCMV belong to the

Corresponding author: K. Kanyuka; E-mail: kostya.kanyuka@bbsrc.ac.uk

* The $\boldsymbol{e}$-Xtra logo stands for "electronic extra" and indicates that four supplemental figures and three supplemental tables are published online. Also, Figure 2 appears in color online. genus Furovirus and contain bipartite single-stranded positivesense RNA genomes. These two furoviruses have been classified as separate species based primarily on sequence divergence: their RNA genomes share approximately only $70 \%$ nucleotide and 60 to $80 \%$ amino acid identity (Diao et al. 1999; Shirako et al. 2000; Torrance and Koenig 2005).

Furoviruses are vectored by the plasmodiophorid Polymyxa graminis (Rao and Brakke 1969), an obligate biotrophic microorganism which naturally inhabits roots of graminaceous plants (Adams and Jacquier 1994; Kanyuka et al. 2003). Based on the internal transcribed spacer (ITS) sequence of nuclear ribosomal RNA genes, temperate $P$. graminis isolates are phylogenetically classified into two subgroups, ribotype I and ribotype II (Ward et al. 1994). Whether biological differences such as host specificity and virus transmission specificity exist between the two $P$. graminis ribotypes is unclear. However, recent studies have reported that $P$. graminis ribotype I preferentially infects barley, whereas $P$. graminis ribotype II is frequently associated with wheat and other cereal species (Vaianopoulos et al. 2007; Ward et al. 2005). Efficient sources of resistance to $P$. graminis have not been identified, and commonly used fungicides are ineffective against plasmodiophorids because they are classified as protists rather than true fungi (Kanyuka et al. 2003). Therefore, the use of Furovirus-resistant cereal genotypes is currently considered to be the only practical means of soilborne mosaic disease control (Bass et al. 2006).

The host response of hexaploid wheat to SBCMV and SBWMV has been well documented. Susceptible genotypes exhibit a mottling or mosaic of the leaves in the spring, after the systemic spread of virus from the primary infected roots to shoots. In the United States and China, yield losses of up to $80 \%$ in susceptible wheat cultivars due to soilborne mosaic disease have been reported (Hou et al. 1985; Hunger et al. 1989). This disease is also a serious constraint to winter wheat production in several European countries (Clover et al. 2001). Resistance to soilborne mosaic disease caused by SBWMV or SBCMV in wheat is rare; however, resistant cultivars have been reported from the United States, Brazil, and Europe (Barbosa et al. 2001; Bass et al. 2006; Modawi et al. 1982). The viruses are undetectable in aerial parts of resistant wheat genotypes but they can usually be detected in roots. Therefore, it is thought that resistance in wheat operates by inhibiting or preventing the upward movement (or "translocation") of furoviruses from infected roots. Hence, this type of resistance has been termed "translocation resistance" (Huth et al. 2007). Even though translocation resistance is effective in preventing crop yield loss, it is incomplete and, therefore, not ideal for sustainable disease control. This is 
because the roots of resistant plants remain reservoirs for viruliferous $P$. graminis and, because resting spores of this organism can remain viruliferous in the soil for at least a decade (Adams 1990), inoculum is likely to amplify with each growing season. Therefore, cereal genotypes which are immune to the virus or fully resistant to the primary transmission of viruses from $P$. graminis into the roots are required. So far, these types of resistance have not been identified in wheat. Interestingly, although SBWMV or SBCMV cannot be detected in the leaves of resistant wheat genotypes following natural (i.e., soil) inoculation, the same genotypes are fully susceptible following artificial virus inoculation onto the leaves (Driskel et al. 2002; Myers et al. 1993). This suggests that resistance in hexaploid wheat does not function in the aerial parts of the plant, and that it is inefficient in blocking downward (i.e., shoot to root) virus translocation.

In contrast to wheat, responses of other cereal species to SBWMV and SBCMV are relatively poorly studied. In addition to hexaploid wheat, Triticum monococcum (einkorn), durum wheat, rye, and triticale are known to be natural hosts of SBCMV and SBWMV (Cadle-Davidson et al. 2006; Kanyuka et al. 2004; Koenig and Huth 2000b; Koenig et al. 1999; Vallega et al. 1999). In the AAB Descriptions of Plant Viruses (Brakke 1971), barley is also listed as a natural host of SBWMV isolates. In early studies, the Japanese barley cv. Nakano Wase was shown to be susceptible to soilborne mosaic in the United States (McKinney 1948). More recently, furoviruses closely related to either the U.S. (Kastirr et al. 2006) or Japanese (Hariri and Meyer 2007) SBWMV strains were isolated from naturally infected barley plants collected from one field in Germany and one field in France, respectively. Interestingly, to date, natural barley infection with SBCMV has not been reported.

The goals of this study were, first, to determine whether barley permits systemic infection by SBCMV and to compare the responses of selected barley genotypes with the two Furovirus spp., SBCMV and SBWMV; and, second, to compare and characterize in depth the resistance mechanisms operating in barley against SBCMV and SBWMV with those operating in hexaploid wheat.

\section{RESULTS}

Barley genotypes respond differentially to SBCMV and SBWMV when naturally inoculated with viruliferous $P$. graminis-infested soils.

Barley cv. Nakano Wase and 21 other barley cultivars, either containing or lacking Nakano Wase in their pedigree, were tested for resistance to two U.K. isolates of SBCMV (SBCMV-Kent and SBCMV-Wilt) and two isolates of SBWMV: one from the United States (SBWMV-Okl) and another from Germany (SBWMV-Hed). Resistance to all Furovirus isolates except SBWMV-Hed was evaluated under glasshouse conditions following inoculation with virus-infested soils. Resistance to SBWMV-Hed was evaluated under field conditions near Heddesheim in Germany. When the plants reached growth stage 5 on the Feekes scale, leaves were tested for presence of Furovirus coat protein (CP) antigen by enzyme-linked immunosorbent assay (ELISA). Roots of plants inoculated in the glasshouse were also tested by ELISA.

Table 1. Response of barley and wheat genotypes to Soilborne wheat mosaic virus (SBWMV) or Soilborne cereal mosaic virus (SBCMV) and their vector Polymyxa graminis following soil inoculation

\begin{tabular}{|c|c|c|c|c|c|c|c|c|}
\hline \multirow[b]{3}{*}{ Genotype } & \multicolumn{4}{|c|}{ SBWMV } & \multicolumn{4}{|c|}{ SBCMV } \\
\hline & \multicolumn{2}{|c|}{ Virus } & \multirow[b]{2}{*}{ Ribotype $^{c}$} & \multirow[b]{2}{*}{ No. of plants ${ }^{d}$} & \multicolumn{2}{|c|}{ Virus } & \multirow[b]{2}{*}{ Ribotype } & \multirow[b]{2}{*}{ No. of plants } \\
\hline & ELISA $^{a}$ & $\mathbf{R N A}^{\mathbf{b}}$ & & & ELISA & RNA & & \\
\hline Black Russian & $\mathrm{S}$ & + & II & 16 & $\mathrm{R}$ & + & I and II & 46 \\
\hline Nakano Wase & $\mathrm{S}$ & + & II & 23 & $\mathrm{R}$ & + & I and II & 48 \\
\hline Iwate Omugi 1 & $\mathrm{~S}$ & nt & II & 10 & $\mathrm{R}$ & + & I and II & 30 \\
\hline Minorimugi & $\mathrm{S}$ & $\mathrm{nt}$ & II & 5 & $\mathrm{R}$ & + & II & 16 \\
\hline Barsoy & $\mathrm{S}$ & + & II & 17 & $\mathrm{R}$ & + & I and II & 24 \\
\hline Maris Otter & $\mathrm{R}$ & nt & nt & 9 & $\mathrm{R}$ & $\mathrm{nt}$ & II & 30 \\
\hline Steptoe & $\mathrm{R}$ & - & II & 8 & $\mathrm{R}$ & - & I and II & 16 \\
\hline Aizu 6 & $\mathrm{R}$ & + & II & 8 & $\mathrm{R}$ & - & I and II & 16 \\
\hline Igri & $\mathrm{R}$ & nt & II & 12 & $\mathrm{R}$ & + & I and II & 16 \\
\hline Parla & $\mathrm{R}$ & + & II & 17 & $\mathrm{R}$ & + & II & 16 \\
\hline Poland & $\mathrm{R}$ & + & II & 8 & $\mathrm{R}$ & - & II & 24 \\
\hline Golden Pheasant & $\mathrm{R}$ & - & II & 15 & $\mathrm{R}$ & - & I and II & 16 \\
\hline Ellis & $\mathrm{R}$ & + & II & 8 & $\mathrm{R}$ & + & I and II & 16 \\
\hline Dayton & $\mathrm{R}$ & + & II & 22 & $\mathrm{R}$ & + & I and II & 30 \\
\hline Esaw & $\mathrm{R}$ & + & I and II & 8 & $\mathrm{R}$ & + & I and II & 16 \\
\hline Harlan Hybrid 1 & $\mathrm{R}$ & - & - & 8 & $\mathrm{R}$ & + & I and II & 16 \\
\hline Admire & $\mathrm{R}$ & + & II & 8 & $\mathrm{R}$ & + & I and II & 16 \\
\hline Abate & $\mathrm{R}$ & + & II & 8 & $\mathrm{R}$ & + & I and II & 16 \\
\hline Morex & $\mathrm{R}$ & nt & - & 13 & $\mathrm{R}$ & + & I and II & 30 \\
\hline Venus & $\mathrm{R}$ & nt & II & 8 & $\mathrm{R}$ & + & I and II & 16 \\
\hline Kenbar & $\mathrm{R}$ & + & II & 8 & $\mathrm{R}$ & + & I and II & 16 \\
\hline Kenate & $\mathrm{R}$ & + & II & 18 & $\mathrm{R}$ & + & I and II & 30 \\
\hline Consort $^{\mathrm{e}}$ & $\mathrm{S}$ & + & II & 25 & $\mathrm{~S}$ & + & II & 29 \\
\hline Avalon ${ }^{\mathrm{e}}$ & $\mathrm{S}$ & + & II & 16 & $\mathrm{~S}$ & + & I and II & 30 \\
\hline Red Chief ${ }^{\mathrm{e}}$ & $\mathrm{S}$ & + & II & 16 & $\mathrm{~S}$ & nt & II & 16 \\
\hline Cadenza $^{\mathrm{e}}$ & $\mathrm{R}$ & nt & nt & 30 & $\mathrm{R}$ & + & I and II & 31 \\
\hline Healthy cv. Consort ${ }^{\mathrm{e}}$ & $\mathrm{R}$ & - & - & 4 & $\mathrm{R}$ & - & - & 4 \\
\hline
\end{tabular}

${ }^{a}$ Enzyme-linked immunosorbent assay. S (susceptible) = coat protein detected in leaves and R (resistant) = coat protein undetected in leaves.

${ }^{\mathrm{b}}$ Results of conventional and real-time reverse-transcriptase polymerase chain reaction (qRT-PCR) designated as presence (+) or absence (-) of amplicon; nt $=$ not tested.

${ }^{\mathrm{c}} P$. graminis ribotype detected by PCR in soil-inoculated roots.

d Total number of plants tested.

${ }^{\mathrm{e}}$ Hexaploid wheat genotypes. 
Nakano Wase barley was fully susceptible to both SBWMV isolates, confirming the results from the earlier study by McKinney (1948). SBWMV was also detected in systemic tissues of barley cvs. Black Russian, Iwate Omugi 1, Minorimugi, and Barsoy by ELISA (Table 1; Supplementary Table 1). In contrast, these five genotypes were consistently resistant to both tested U.K. isolates of SBCMV. Although low titers of SBCMV CP were detected in the roots of $<20 \%$ of Black Russian and $<5 \%$ of Nakano Wase plants examined, furoviral CP was not detected in the leaves of these plants (Table 1). SBCMV virions were also undetectable by transmission electron microscopy (TEM) in crude virus preparations from leaves of Nakano Wase and Black Russian in two separate experiments (data not shown). In addition, using reverse-transcriptase polymerase chain reaction (RT-PCR), neither SBCMV-Kent nor SBCMV-Wilt was detectable in total RNA preparations from the leaves of naturally inoculated Nakano Wase and Black Russian (data not shown).

Interestingly, of the remaining 17 barley genotypes tested, Furovirus CP was undetectable in leaves and roots following natural inoculation with soils infested with any of the Furovirus spp. or isolates (Table 1). This suggests that barley may have developed a different and more efficient resistance (and possibly immunity) to furoviruses than the translocation resistance known in wheat.

\section{Resistance is directed toward the viruses rather than their vector, $P$. graminis.}

Previous studies suggested that $P$. graminis ribotype I may preferentially infect barley and transmit bymoviruses such as Barley yellow mosaic virus and Barley mild mosaic virus, whereas $P$. graminis ribotype II may preferentially infect wheat and transmit SBCMV (Vaianopoulos et al. 2007; Ward et al. 2005). Therefore, one possible explanation for the differential barley response to the two Furovirus spp. observed in this study was that the different soils used for inoculation may have contained different $P$. graminis ribotypes, or that the two $P$. graminis ribotypes may have preferentially infected specific barley genotypes. To test these hypotheses, $P$. graminis ribotype-specific PCR was used to explore which $P$. graminis ribotypes had infected each barley genotype inoculated with the different soils. Both $P$. graminis ribotypes were previously detected in SBCMV-Kent soils (M. Smith, Rothamsted Research, personal communication) and both $P$. graminis ribotypes are known to be present in the SBWMVHed infested field (W. Huth, Federal Biological Research Centre for Agriculture and Forestry, Germany, personal communication). Using $P$. graminis ribotype-specific PCR assays, we detected $P$. graminis ribotype II in roots of the majority of both barley and wheat genotypes grown in SBCMV-Kent- and SBWMV-Okl-infested soils, whereas $P$. graminis ribotype I was detected in only one barley cultivar grown in SBWMV-Okl-infested soil and in none of the plants grown in SBCMV-Kent soil. On the other hand, both $P$. graminis ribotypes were detected in the roots of barley and wheat genotypes grown in SBCMV-Wilt-infested soil (Table 1; Supplementary Fig. 1 and Supplementary Table 2).

In summary, no correlation was identified between cultivar resistance and the presence of a particular $P$. graminis ribotype or between the particular soil inoculum used and the particular $P$. graminis ribotypes detected in the infected barley roots. Thus, for example, $P$. graminis ribotype II was detected not only in the roots of barley genotypes systemically infected with SBCMV or SBWMV but also in the roots of resistant genotypes (Table 1$)$. This suggests that $P$. graminis ribotype II is capable of transmitting both Furovirus spp. and that the resistance to soilborne mosaic disease in barley, as in wheat, is directed toward the viruses rather than to their vector, $P$. graminis.

\section{Very low levels of Furovirus RNA but not viral CP can be detected in roots of resistant barley genotypes.}

Although soil-inoculated barley genotypes exhibiting resistance to soilborne mosaic disease contained $P$. graminis in their roots (Table 1), it was not obvious whether this $P$. graminis was viruliferous or nonviruliferous. To answer this question, the roots of barley genotypes grown in the soils infested with SBCMV-Kent, SBCMV-Wilt, and SBWMV-Okl were analyzed by RT-PCR for the presence of furoviral RNA. Interestingly, faint amplification products of the expected size were detected from roots of resistant barley genotypes (i.e., those showing no mosaic symptoms and lacking viral $\mathrm{CP}$ in both shoots and roots) (Table 1; Supplementary Fig. 2). These data suggest that $P$. graminis detected in the roots of these resistant genotypes was viruliferous.

To quantify and compare the levels of viral RNA present in roots of barley genotypes following natural inoculation, a quantitative (real-time) RT-PCR (qRT-PCR) assay was designed. Primers SBCMVCPF and SBCMVCPR that were previously designed for use with a Taqman probe by Ratti and associates (2004) were found to be unsuitable for the SYBR green-based detection method (Supplementary Fig. 3A). Therefore, several new pairs of primers for qRT-PCR were generated. Two of the best-performing primer pairs, which were located in the CP cistron of SBCMV RNA2 (qSBCMV-F and qSBCMV-R) and in the $3^{\prime}$ untranslated region of SBWMV RNA2 (qSBWMV-F and qSBWMV-R), were used for the assay (Table 2). For increased sensitivity of detection, the primers were designed to allow amplification of short (71-bp) virus target sequences. These new primers

Table 2. Sequences of primers designed for quantitative (real-time) reverse-transcriptase polymerase chain reaction (qRT-PCR) analysis of virus abundance in plant tissues

\begin{tabular}{|c|c|c|c|c|c|c|c|}
\hline \multirow[b]{2}{*}{ Accession $^{b}$} & \multirow[b]{2}{*}{ Primer name } & \multirow[b]{2}{*}{ Primer sequence, $5^{\prime}-3^{\prime}$} & \multirow[b]{2}{*}{ Position (nt) ${ }^{c}$} & \multicolumn{3}{|c|}{ Amplicon size, bp $^{\mathbf{a}}$} & \multirow[b]{2}{*}{ Efficiency $^{\mathrm{d}}$} \\
\hline & & & & SBCMV & SBWMV & Barley/wheat & \\
\hline \multirow[t]{2}{*}{ AJ298069 } & qSBCMV-F & GCCGACTACCAACCAAGTTGA & $663-683$ & 71 & 0 & 0 & 1.919 \\
\hline & qSBCMV-R & GCGCATTCGAAATGGCTAAC & $714-733$ & & & & \\
\hline \multirow[t]{2}{*}{ X81639 } & qSBWMV-F & AGCTGGTAAAGTGACTGCTGAATCTA & $267-292$ & 0 & 71 & 0 & 1.840 \\
\hline & qSBWMV-R & CCATAACTGGCAAGGGTGTAGTAAC & $313-337$ & & & & \\
\hline \multirow[t]{2}{*}{ AJ699059 } & qeIF4E-F & GCCGACTTCCATTGCTTCAA & $387-406$ & 0 & 0 & 71 & 1.895 \\
\hline & qeIF4E-R & TTACCGCCATTGGCACAA & $439-457$ & & & & \\
\hline
\end{tabular}

${ }^{\text {a }}$ SBCMV = Soilborne cereal mosaic virus and SBWMV = Soilborne wheat mosaic virus.

${ }^{\mathrm{b}}$ GenBank accession number. Viral and plant nucleotide sequences used for primer design.

${ }^{\mathrm{c}}$ Nucleotide (nt) positions of primers within the sequence of the corresponding GenBank accession.

${ }^{\mathrm{d}}$ Primer pairs were used to amplify serial dilutions of the cDNA template mixes to generate a standard curve. The PCR efficiency (E) was calculated according to Rasmussen (2001). 
were shown to be virus species specific, and no primer dimers were formed as assessed using dissociation curve analyses and gel electrophoresis (data not shown). A pair of primers, qeIF4E-F and qeIF4E-F, was designed from the conserved region of the plant eukaryotic translation initiation factor $4 E$ (eIF4E) gene to allow efficient detection of corresponding mRNA transcripts from both barley and wheat tissues (Table 2). The $e I F 4 E$ gene was considered a reliable endogenous reference because there were no trends in cycle threshold $(\mathrm{Ct})$ values of eIF4E qRT-PCR amplicons between different tissues, time points, or plant species (i.e., barley and wheat) amplified from the same concentration of starting RNA. The mean reaction efficiency values for each primer pair were $\mathrm{SBCMV}=1.915, \mathrm{SBWMV}=1.840$, and $e I F 4 E=$ 1.895 (Table 2) and all standard curves used in the study showed a high level of linearity $\left(R^{2}>0.95\right)$.

The quantity of qRT-PCR product detected in the roots of barley genotypes resistant to SBWMV-Okl ranged from approximately 12-fold less (Aizu 6) (Fig. 1A) to approximately 7,000-fold less (Ellis) (Fig. 1A) than in roots of susceptible Black Russian barley. Similar data were obtained for barley genotypes showing resistance to SBCMV. Roots of these genotypes contained between 5-fold (Admire) and 300-fold (cv.
Parla) less SBCMV than roots of barley Black Russian in which the viral $\mathrm{CP}$ was detected by ELISA (Fig. 1B). Interestingly, there was $>2,000$-fold less SBCMV RNA in roots of barley Black Russian than in roots of highly susceptible Consort wheat grown in the same soil (Fig. 1B). These data additionally confirm that resistance to soilborne mosaic disease in barley is directed toward the viruses rather than P. graminis.

\section{Breakdown of resistance can be achieved \\ in some barley genotypes} by artificial virus inoculation onto the leaves.

Each of the virus isolates (i.e., SBCMV-Kent, SBCMV-Wilt, SBWMV-Okl, and SBWMV-Hed) was rub inoculated onto the leaves of young seedlings of 14 barley genotypes. At 4 weeks postinoculation (wpi), the plants were assessed for the presence of typical mosaic symptoms and then systemic leaves and roots were collected and tested by ELISA. In addition, tissue print immunoassays (TPIA) were undertaken to investigate and compare the distribution of viral CP in tissues of barley genotypes inoculated with different Furovirus isolates.

As expected, the barley genotypes exhibiting full susceptibility to SBWMV following natural inoculation (i.e., Nakano Wase, Black Russian, Iwate Omugi 1, Minorimugi, and Bar-
A

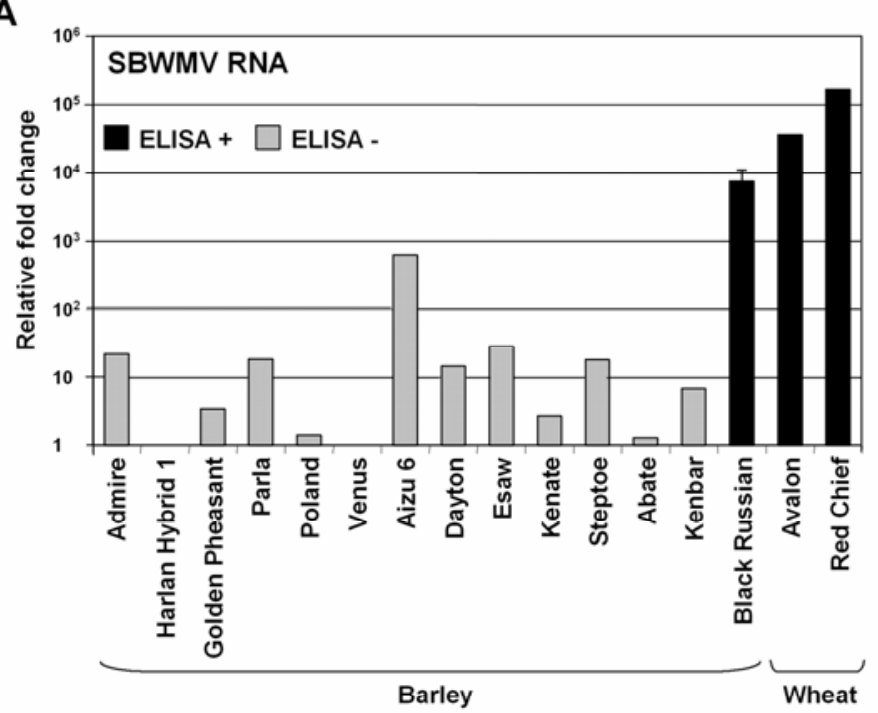

B

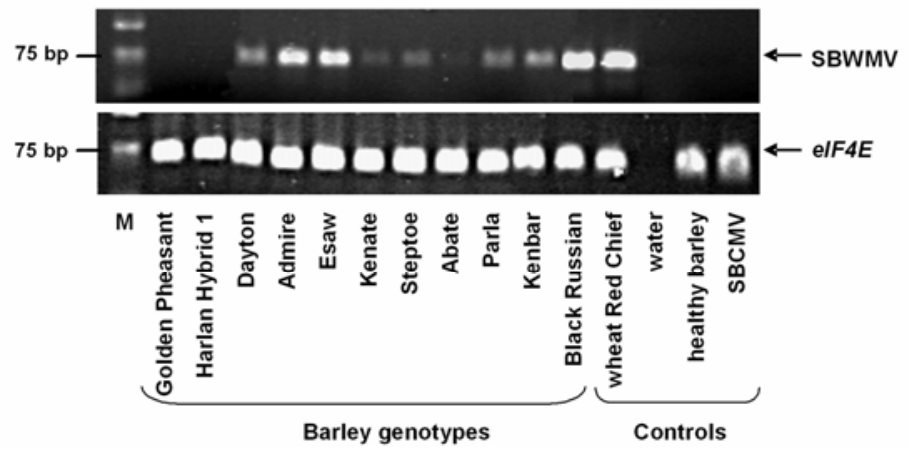

C

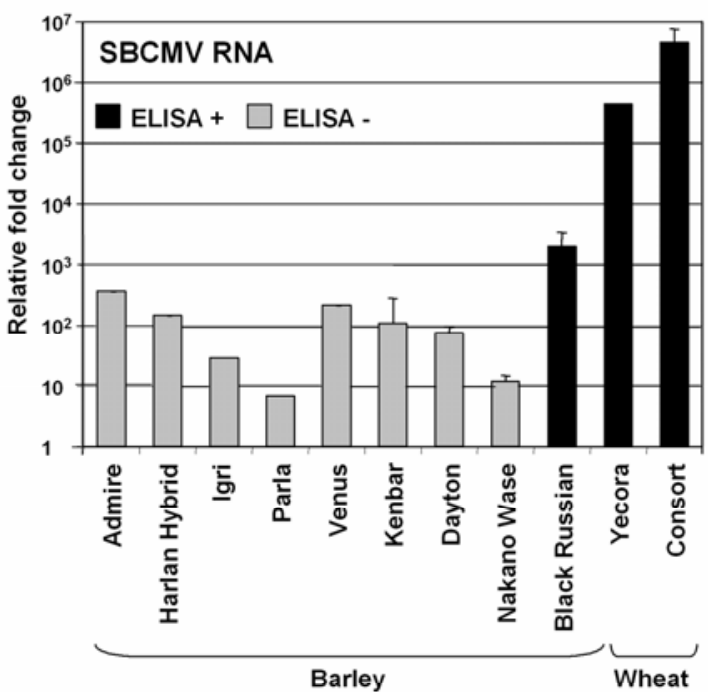

D

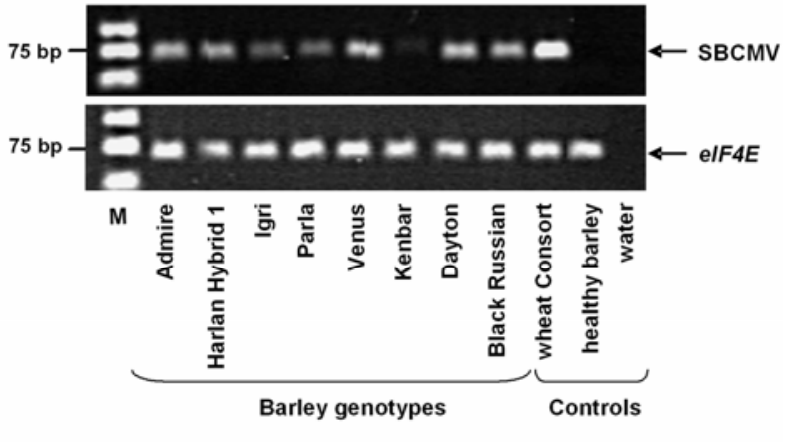

Fig. 1. Quantification of viral RNA in roots of soil-inoculated plants. Relative fold changes in the amount of viral RNA detected by $\mathbf{A}$ and $\mathbf{C}$, quantitative reverse-transcriptase polymerase chain reaction (qRT-PCR) and $\mathbf{B}$ and $\mathbf{D}$, gel electrophoresis of viral eIF4E qRT-PCR products from roots of plants grown in soils infested with A and B, Soilborne wheat mosaic virus (SBWMV)-Okl and C and D, Soilborne cereal mosaic virus (SBCMV)-Kent collected at 12 weeks postinoculation. Leaves of Consort wheat infected with SBCMV-Kent and roots of Red Chief wheat infected with SBWMV-Okl were used as negative controls in SBWMV-specific and SBCMV-specific assays, respectively. The healthy leaves of Dayton barley were used as an additional negative control. Fold changes are relative to samples showing the lowest normalized expression values for each set of virus primers. Black bars indicate the virus is detectable by enzyme-linked immunosorbent assay (ELISA) and RT-PCR; gray bars indicate that virus is undetectable by ELISA but detectable by RT-PCR. Error bars represent the standard error of the biological replicates. $\mathrm{M}=$ Low molecular weight DNA marker (New England Biolabs); the 75-bp DNA fragment is indicated. 
soy) were systemically infected when this virus was artificially inoculated onto the leaves (Table 3 ). In addition, several barley genotypes which were classified as resistant in soil inoculation tests permitted systemic infection when SBWMV or SBCMV were artificially inoculated onto the leaves (e.g., Parla and Ellis versus SBWMV and Black Russian and Nakano Wase versus SBCMV) (Table 3; Fig. 2; Supplementary Fig. 4). Therefore, some barley genotypes, similarly to wheat, possess the translocation-type resistance against furoviruses.

Interestingly, barley genotypes Steptoe, Aizu 6, and Igri, which exhibited resistance to both SBCMV and SBWMV in natural inoculation tests, displayed a differential reaction to these two Furovirus spp. in manual inoculation tests. That is, these genotypes permitted systemic infection with SBWMV but not with SBCMV (Table 3; Fig. 2). This datum is an additional proof that SBCMV and SBWMV have different biological properties.

Importantly, one barley genotype exhibited resistance to both SBCMV and SBWMV in artificial inoculation tests. Dayton displayed no mosaic symptoms and contained no viral $\mathrm{CP}$ in the systemic tissues following rub inoculation onto the leaves with any of the four Furovirus isolates in several independent experiments (Table 3; Fig. 2). Therefore, Dayton barley possesses resistance to furoviruses that is more efficient than translocation resistance. This novel type of resistance in barley will be referred to hereafter as "extreme resistance."

\section{Only traces of furoviral RNA can be detected in systemic tissues of extremely resistant barley genotypes following artificial virus inoculation onto the leaves.}

The systemic leaves of artificially virus-inoculated plants, in which neither mosaic symptoms nor viral $\mathrm{CP}$ had been detected using immunological methods (i.e., ELISA and TPIA), were subjected to qRT-PCR analyses for detection of furoviral RNA. In systemic leaves of barley genotypes exhibiting extreme resistance to SBCMV (i.e., Dayton, Steptoe, Poland, and Golden Pheasant) and SBWMV (i.e., Dayton and Poland), viral RNA was either completely absent or present at concentrations close to the limit of qRT-PCR detection. Furoviral RNA was also undetectable by qRT-PCR in the roots of these barley genotypes (Fig. 3).
Extreme resistance operates by preventing spread of Furovirus spp. from the primary inoculated cells.

The combined natural and artificial virus inoculation datasets suggest one or more of the following mechanisms for extreme resistance to furoviruses in barley: i) complete prevention of virus replication and spread in the leaves (i.e., immunity), ii) inhibition of virus replication, iii) restriction of virus local or systemic movement, or iv) efficient antiviral RNA silencing in primary inoculated or systemic tissues. To probe these hypotheses, concentrations of furoviral RNA in rub-inoculated leaves of the following genotypes were examined by qRT-PCR: barley cv. Dayton (extreme resistance), barley cvs. Ellis and Parla (translocation resistance), and wheat cv. Consort (susceptibility). At 40 $\mathrm{h}$ postinoculation (hpi), similar relative concentrations of SBCMV and SBWMV RNA were detected in the inoculated leaves of all tested genotypes (Fig. 4). Even though rub-inoculated leaves had been copiously sprayed with tap water at 2 to 5 min postinoculation, there was a formal possibility that the qRTPCR products detected at 40 hpi were derived from viral RNA in the residual sap inoculum on the leaf surface. To eliminate this possibility and to compare the kinetics of viral RNA accumulation in rub-inoculated leaves of Dayton barley with other resistant and susceptible genotypes, qRT-PCR was performed on total RNA isolated from SBCMV-Kent-inoculated leaves at 2, 4, 7,11 , and 20 days postinoculation (dpi). Viral RNA was detected in inoculated leaves of all tested genotypes and at all time points (Fig. 5). However, at $20 \mathrm{dpi}$, the relative concentration of viral RNA in rub-inoculated leaves of extremely resistant Dayton and Steptoe was notably lower than in other genotypes. Moreover, between 2 and $4 \mathrm{dpi}$ and $20 \mathrm{dpi}$, the concentration of viral RNA in rub-inoculated leaves of Consort wheat and Black Russian and Parla barley significantly increased, suggesting efficient virus accumulation. In contrast, there was either no (Dayton) or very little (Steptoe) increase in the concentration of SBCMV RNA in extremely resistant barley genotypes (Fig. 5). These data argue against immunity to furoviruses in both root and leaf tissues as well as against efficient antiviral RNA silencing in primary inoculated leaf tissues of barley cvs. Dayton and Steptoe. Therefore, it seemed most likely that the extreme resistance in barley operates by inhibiting either Furovirus replication or viral spread from the primary inoculated cells to naïve neighboring cells.

Table 3. Responses of barley cultivars to isolates of two different Furovirus species following natural and artificial inoculations ${ }^{\mathrm{a}}$

\begin{tabular}{|c|c|c|c|c|c|c|c|c|c|c|c|c|}
\hline \multirow[b]{2}{*}{ Genotype } & \multicolumn{3}{|c|}{ SBWMV-Okl } & \multicolumn{3}{|c|}{ SBWMV-Hed } & \multicolumn{3}{|c|}{ SBCMV-Wilt } & \multicolumn{3}{|c|}{ SBCMV-Kent } \\
\hline & $\mathbf{N I}^{\mathbf{b}}$ & $\mathbf{A I}^{\mathbf{c}}$ & No. ${ }^{d}$ & NI & AI & No. & NI & AI & No. & NI & $\mathbf{A I}$ & No. \\
\hline Black Russian & $\mathrm{S}$ & $\mathrm{S}$ & 8 & $\mathrm{~S}$ & $\mathrm{~S}$ & 8 & $\mathrm{R}$ & $S$ & 8 & $\mathrm{R}$ & $\mathrm{S}$ & 38 \\
\hline Nakano Wase & $\mathrm{S}$ & $\mathrm{S}$ & 8 & $\mathrm{~S}$ & $\mathrm{~S}$ & 8 & $\mathrm{R}$ & $S$ & 8 & $\mathrm{R}$ & $\mathrm{S}$ & 8 \\
\hline Iwate Omugi 1 & $\mathrm{~S}$ & $\mathrm{~S}$ & 8 & $S$ & $\mathrm{~S}$ & 8 & $\mathrm{R}$ & $\mathrm{R}$ & 8 & $\mathrm{R}$ & $\mathrm{R}$ & 8 \\
\hline Barsoy & $\mathrm{S}$ & $\mathrm{S}$ & 8 & $\mathrm{R}$ & $\mathrm{S}$ & 8 & $\mathrm{R}$ & $\mathrm{R}$ & 8 & $\mathrm{R}$ & $\mathrm{R}$ & 8 \\
\hline Maris Otter & $\mathrm{R}$ & $\mathrm{S}$ & 8 & $\mathrm{R}$ & $\mathrm{S}$ & 8 & $\mathrm{R}$ & $\mathrm{S}$ & 8 & $\mathrm{R}$ & $\mathrm{S}$ & 8 \\
\hline Minorimugi & $\mathrm{R}$ & $\mathrm{S}$ & 8 & $\mathrm{~S}$ & $\mathrm{~S}$ & 8 & $\mathrm{R}$ & $\mathrm{S}$ & 8 & $\mathrm{R}$ & $\mathrm{S}$ & 7 \\
\hline Steptoe & $\mathrm{R}$ & $\mathrm{S}$ & 6 & $\mathrm{R}$ & $\mathrm{S}$ & 8 & $\mathrm{R}$ & $\mathrm{R}$ & 8 & $\mathrm{R}$ & $\mathrm{R}$ & 8 \\
\hline Aizu 6 & $\mathrm{R}$ & $\mathrm{S}$ & 8 & $\mathrm{R}$ & $\mathrm{S}$ & 8 & $\mathrm{R}$ & $\mathrm{R}$ & 8 & $\mathrm{R}$ & $\mathrm{R}$ & 8 \\
\hline Igri & $\mathrm{R}$ & $\mathrm{S}$ & 16 & $\mathrm{R}$ & $\mathrm{S}$ & 16 & $\mathrm{R}$ & $\mathrm{R}$ & 8 & $\mathrm{R}$ & $\mathrm{R}$ & 6 \\
\hline Parla & $\mathrm{R}$ & $\mathrm{S}$ & 8 & $\mathrm{R}$ & $\mathrm{S}$ & 8 & $\mathrm{R}$ & $\mathrm{R}$ & 8 & $\mathrm{R}$ & $\mathrm{S}$ & 8 \\
\hline Poland & $\mathrm{R}$ & $\mathrm{R}$ & 6 & $\mathrm{R}$ & $\mathrm{S}$ & 8 & $\mathrm{R}$ & $\mathrm{R}$ & 16 & $\mathrm{R}$ & $\mathrm{R}$ & 8 \\
\hline Golden Pheasant & $\mathrm{R}$ & $\mathrm{S}$ & 8 & $\mathrm{R}$ & $\mathrm{R}$ & 8 & $\mathrm{R}$ & $\mathrm{R}$ & 8 & $\mathrm{R}$ & $\mathrm{R}$ & 6 \\
\hline Ellis & $\mathrm{R}$ & $\mathrm{S}$ & 8 & $\mathrm{R}$ & $\mathrm{S}$ & 8 & $\mathrm{R}$ & $\mathrm{R}$ & 8 & $\mathrm{R}$ & $\mathrm{S}$ & 8 \\
\hline Dayton & $\mathrm{R}$ & $\mathrm{R}$ & 15 & $\mathrm{R}$ & $\mathrm{R}$ & 15 & $\mathrm{R}$ & $\mathrm{R}$ & 8 & $\mathrm{R}$ & $\mathrm{R}$ & 8 \\
\hline Wheat cv. Consort & $\mathrm{S}$ & $\mathrm{S}$ & 29 & $\mathrm{~S}$ & $\mathrm{~S}$ & 30 & $\mathrm{~S}$ & $\mathrm{~S}$ & 26 & $\mathrm{~S}$ & $\mathrm{~S}$ & 8 \\
\hline
\end{tabular}

${ }^{\text {a }}$ SBWMV = Soilborne wheat mosaic virus from Oklahoma, United States (Okl) and Heddesheim, Germany (Hed). SBCMV = Soilborne cereal mosaic virus from Wiltshire and Kent, United Kingdom (Wilt and Kent, respectively).

${ }^{\mathrm{b}}$ Detection of furoviruses by enzyme-linked immunosorbent assay (ELISA) in leaves of naturally inoculated (NI) plants at 8 to 12 weeks postinoculation (wpi). S (susceptible) indicates viral coat protein $(\mathrm{CP})$ was detected and R (resistant) indicates viral $\mathrm{CP}$ was undetected.

${ }^{\mathrm{c}}$ Detection of furoviruses by ELISA in both roots and systemic leaves of artificially inoculated (AI) plants at 4 wpi. S (susceptible) indicates viral CP was detected in either roots or systemic leaves and $\mathrm{R}$ (resistant) indicates viral CP was undetected in both systemic leaves and roots.

$\mathrm{d}$ Total number of artificially inoculated plants. 
To distinguish between these two possibilities, SBCMV or SBWMV were rub inoculated onto the distal halves of primary leaves of susceptible barley and wheat genotypes and the extremely resistant barley genotype Dayton. At $21 \mathrm{dpi}$, total RNA was extracted from the rub-inoculated half of the leaf, the uninoculated half of the same leaf, the leaf sheath, and the young systemic leaf just above the point of inoculation. The roots and stem were also collected from plants inoculated with SBWMV. All RNA samples were subjected to qRT-PCR analysis. SBCMV RNA was present in similar concentrations in the inoculated halves of leaves of all tested genotypes at this time point (Fig. 6A). This suggests that viral replication is not compromised in leaf cells of extremely resistant barley cv. Dayton. SBCMV and SBWMV RNA was present at significantly lower concentrations in the uninoculated halves of leaves and the leaf sheath of the inoculated leaf, and were completely absent in the systemic tissues of Dayton (Fig. 6). Therefore, we conclude that the extreme re- sistance is efficient in both restricting the local and preventing the systemic virus spread.

\section{DISCUSSION}

Following the initial descriptions of SBWMV (McKinney $1930,1937)$, it has generally been accepted that barley is a host to this virus. Ensuing studies of SBWMV and related viruses in barley, in contrast to wheat and rye, have been quite limited. In previous studies aiming to identify sources of efficient resistance to $P$. graminis, a vector of a large number of soilborne viruses, including the furoviruses SBCMV and SBWMV, the U.K. barley cv. Maris Otter was randomly selected as a positive control in the inoculation tests (Ward et al. 2005). In one experiment, Maris Otter was inoculated with the soil from Kent, U.K., which was heavily infested with $P$. graminis harboring SBCMV. Even though roots of all tested barley plants contained $P$. graminis, mosaic symptoms were
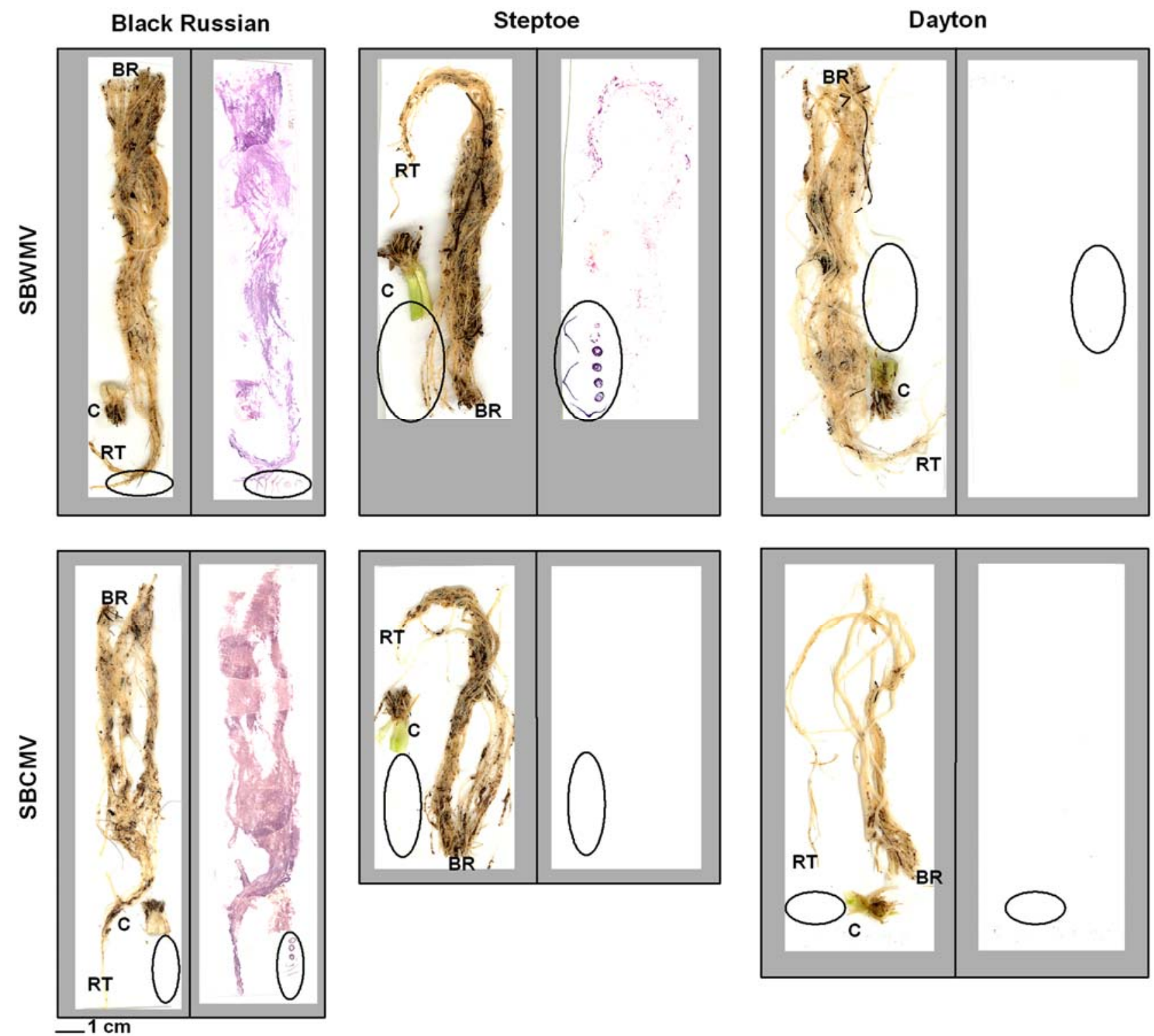

Fig. 2. Tissue-print immunoassay for detection of viral coat protein (CP) antigen in artificially inoculated plants. Plant tissues were collected at 4 weeks postinoculation. The left image in each panel shows the position of roots (BR = basal root and RT = root tip) and crown (C) as well as stem and leaf cross sections (circled) on the membranes prior to immunolocalization. The right image in each panel shows the localization of CP antigen on the membrane (purple coloration). The upper panels show tissue prints of plants inoculated with Soilborne wheat mosaic virus (SBWMV) and the lower panels show tissue prints of plants inoculated with Soilborne cereal mosaic virus (SBCMV). Furoviral CP was detected in all tissues of susceptible Black Russian barley, whereas it is undetectable in any tissue of extremely resistant Dayton barley. 
not observed and the SBCMV CP was undetectable by ELISA in either leaves or roots of these plants (Ward et al. 2005). This serendipitous discovery prompted us to investigate the response of additional barley genotypes to SBCMV and SBWMV in the current study. Here, we report that susceptibility to SBWMV in barley is relatively rare. Among the 22 barley genotypes tested, only 5 were susceptible to SBWMV, and none of these barley genotypes were susceptible to SBCMV when the natural inoculation method (i.e., growing plants in soils infested with viruliferous $P$. graminis) was used. Therefore, it appears that, in contrast to wheat, barley germplasm is a rich and virtually unexplored source of resistance to furoviruses. Wheat genotypes exhibiting the so-called translocation resistance, the only known type of resistance to furoviruses identified to date in wheat, can be readily infected when either virus is artificially inoculated onto their leaves. In this study, we identified several barley genotypes that were resistant to either SBWMV or SBCMV, and one (Dayton) that was resistant to both Furovirus spp. following both natural inoculation with viruliferous soils onto the roots and artificial rub inoculation with viruscontaining plant sap onto the leaves. Further molecular analyses suggested that this novel and highly efficient type of resistance to furoviruses in barley operates by limiting viral spread from the primary inoculated cells. We propose the term "extreme resistance" to describe this resistance response type.

Specific detection of two major ribotypes of the vector species $P$. graminis by PCR allowed us to assess the possible role of $P$. graminis in resistance to soilborne mosaic disease in barley. Although $P$. graminis was detected in the majority of the plants tested, we found evidence for neither a genotype-specific resistance to the particular $P$. graminis ribotype nor the selective ability of particular $P$. graminis ribotype to vector SBWMV or SBCMV. Also, in contrast to recent studies (Vaianopoulos et al. 2007; Ward et al. 2005), we found no convincing evidence for host specialization of $P$. graminis ribotypes. Therefore, resistance to soilborne mosaic in barley is directed toward the viruses rather than their vector.

Following natural inoculation, all tested barley genotypes were resistant to SBCMV and many exhibited resistance to SBWMV. Furoviral CP was undetectable by ELISA in leaves and in roots of these resistant genotypes. Furoviral RNA was also undetectable in the leaves of resistant barley genotypes when a very sensitive detection assay, qRT-PCR, was used. However, furoviral RNA was detected in the roots of resistant barley genotypes, albeit at low relative concentrations (compared with susceptible genotypes), suggesting that these genotypes are not immune to furoviruses (Fig. 1). Viral CP was undetectable but viral RNA was detectable in root tissues; therefore, it seems possible that that the viruses were present as naked RNA or ribonucleoprotein complexes. Alternatively, the RT-PCR products may have been derived from nonreplicating viral RNA templates present either in the initially infected root

Fig. 3. Quantification of viral RNA in systemic tissues of artificially inoculated plants. Relative fold changes in the amount of viral RNA detected by quantitative reverse-transcriptase polymerase chain reaction (qRT-PCR) in systemic leaves (L) or roots (R) of barley and wheat plants collected at 4 weeks postinoculation with A, Soilborne cereal mosaic virus SBCMV or B, Soilborne wheat mosaic virus SBWMV. Black bars indicate the virus is detectable by enzyme-linked immunosorbent assay (ELISA) and RT-PCR; gray bars indicate that virus is undetectable by ELISA but detectable by qRT-PCR. Error bars represent standard error of biological replicates. C, Gel electrophoresis of qRT-PCR products of SBWMV and the plant housekeeping gene eIF4E. Healthy leaves of Dayton barley were used as a negative control. $\mathrm{M}=$ Low molecular weight DNA marker (New England Biolabs); the 75-bp DNA fragment is indicated. cells only or within $P$. graminis zoospores or plasmodia that had failed to release viruses into the plant root cells.

Resistant barley genotypes were artificially inoculated (rub inoculated) with SBCMV and SBWMV to investigate the under-

A

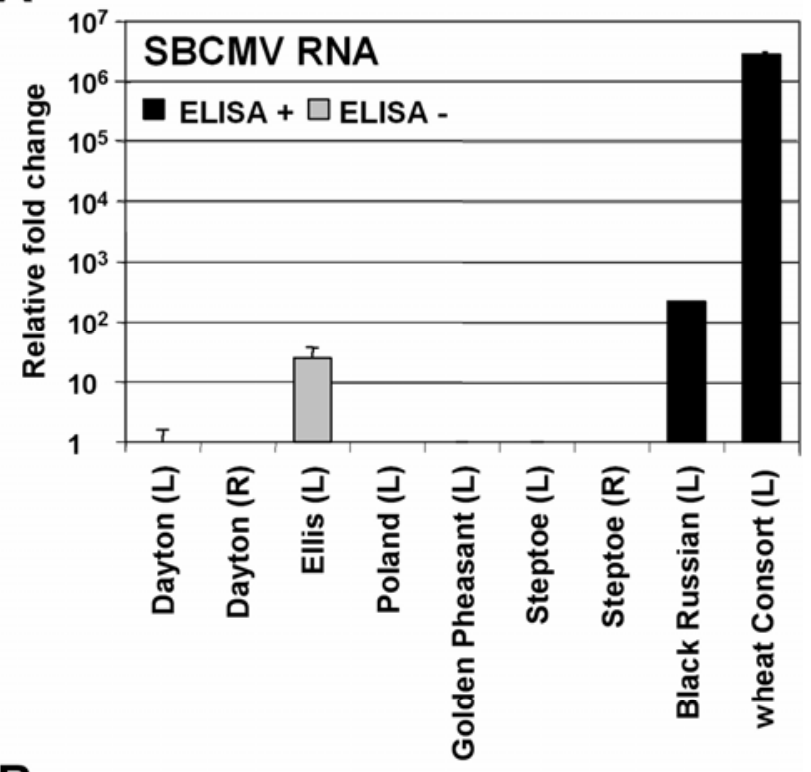

B
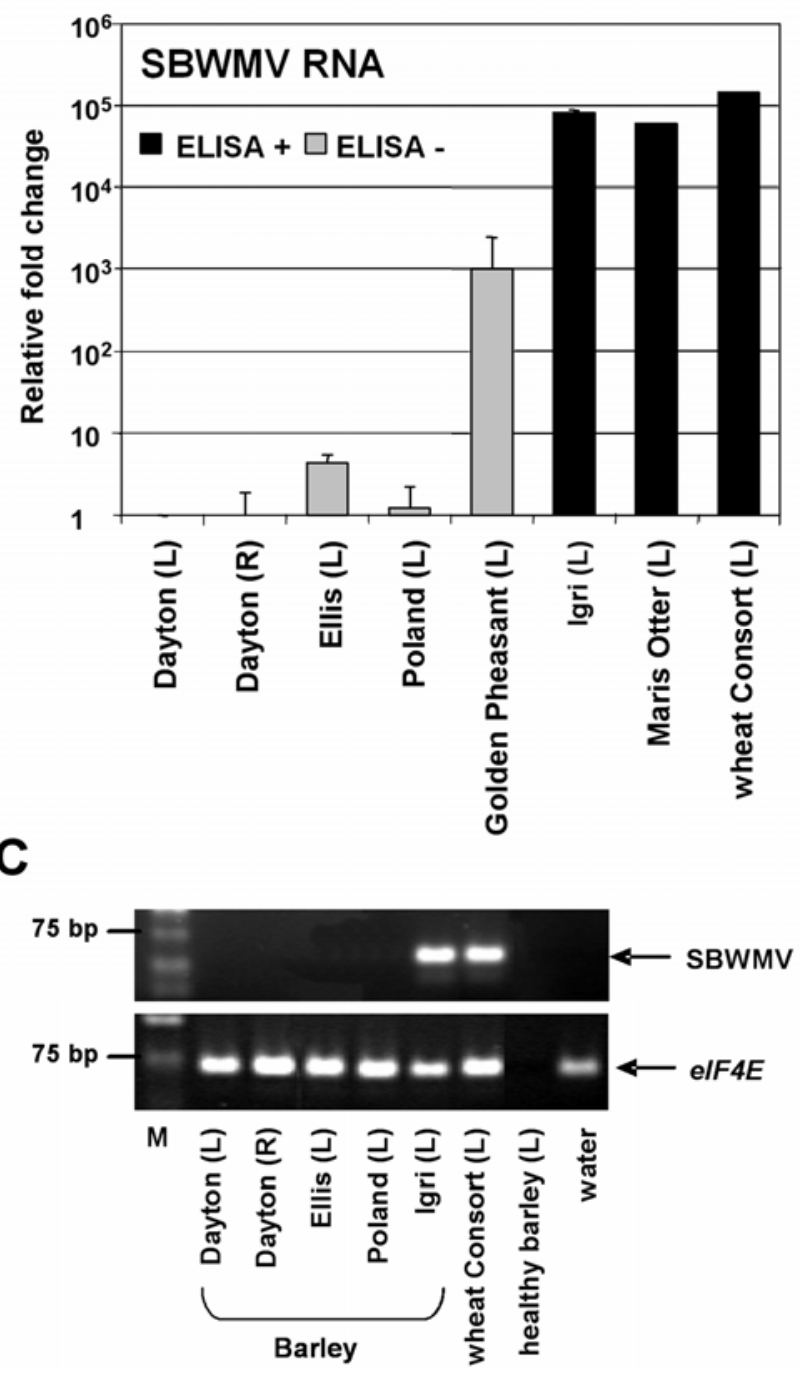
lying mechanism of resistance. At 3 to 4 weeks post-artificial inoculation, several barley genotypes (e.g., Maris Otter) had developed typical mosaic symptoms and furoviral $\mathrm{CP}$ had accumulated in the young (systemic) leaves and also in the roots (Table 3). This suggests that resistance in these barley genotypes was not tissue specific and that it may operate by imposing an efficient block on virus translocation from root to

\section{A}
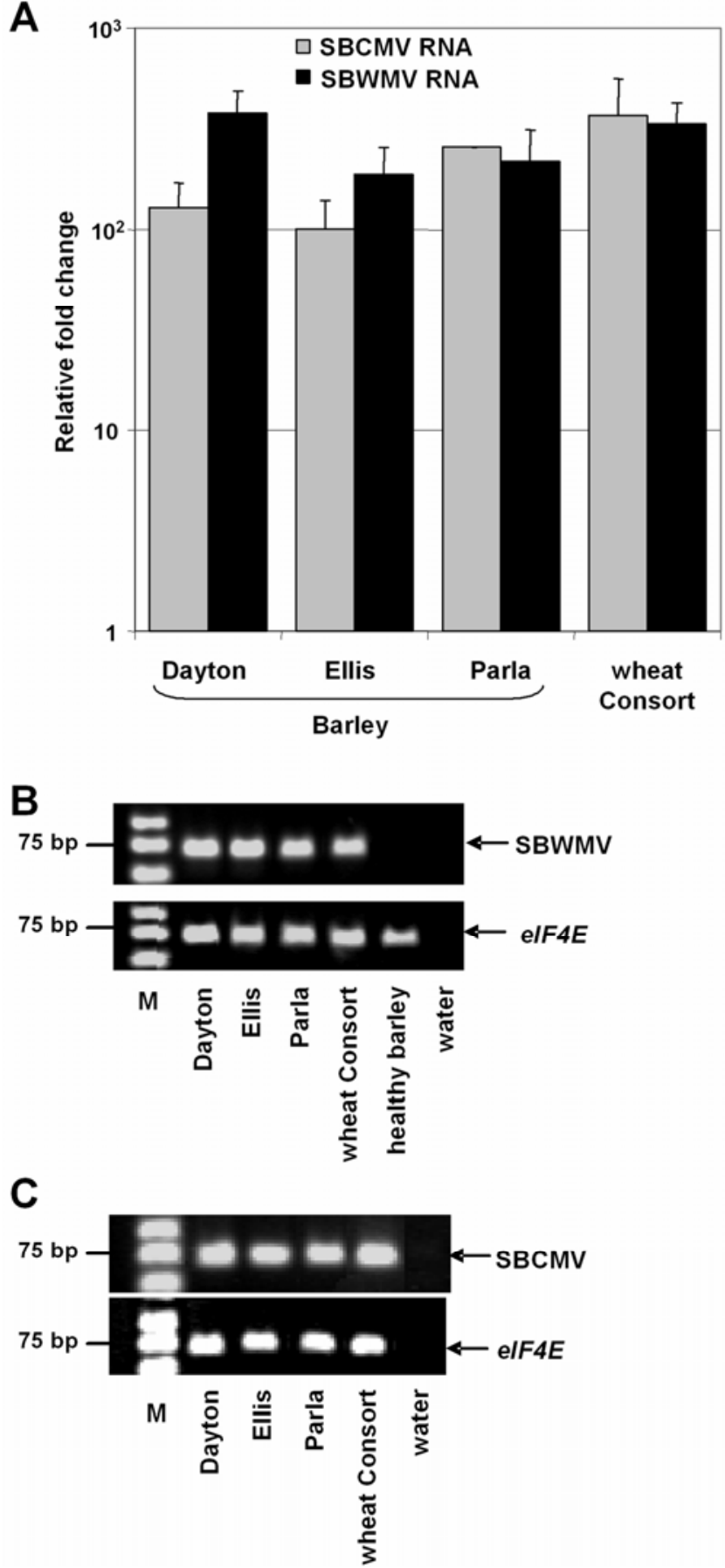

Fig. 4. Quantification of viral RNA in artificially inoculated leaves at $40 \mathrm{~h}$ postinoculation (hpi). Relative fold changes in the amount of viral RNA detected by $\mathbf{A}$, quantitative reverse-transcriptase polymerase chain reaction (qRT-PCR) and B, gel electrophoresis of viral and eIF4E qRT-PCR products in leaves of barley and wheat plants inoculated with $\mathbf{B}$, Soilborne wheat mosaic virus (SBWMV)-Hed or $\mathbf{C}$, Soilborne cereal mosaic virus (SBCMV)-Kent. Leaves were collected at 40 hpi. Error bars represent standard error of biological replicates. Healthy leaves of Dayton barley were used as a negative control. $\mathrm{M}=$ Low molecular weight DNA marker (New England Biolabs); the 75-bp DNA fragment is indicated. shoot. A similar mechanism for resistance (the so-called translocation resistance) has been proposed to operate in wheat (Huth et al. 2007). Previous investigations have proposed that systemic upward (i.e., from root to shoot) movement of SBWMV in wheat occurs predominantly via the xylem (Verchot et al. 2001), whereas the most likely route by which furoviruses are transported from the infected leaves to roots and young leaves is the phloem. Therefore, is it conceivable that resistance in Maris Otter barley and some other genotypes (Table 3) blocks Furovirus entry into the xylem vessels but is ineffective in blocking the virus entry, transport, and exit from the phloem elements. Alternatively, the resistance exhibited following natural inoculation in these barley genotypes may operate by inhibiting the initial virus transmission from $P$. graminis into the root cells.

Importantly, we also identified several barley genotypes in which viral $\mathrm{CP}$ was absent from all tissues after both natural and manual inoculation with either SBWMV or SBCMV. Moreover, barley cv. Dayton exhibited resistance to all tested isolates of both Furovirus spp. This novel type of resistance (i.e., extreme resistance), which has not previously been identified in wheat or other cereal species, is not manifested as immunity because low amounts of viral RNA were detectable in the inoculated tissues. Moreover, viral RNA was detectable in the artificially inoculated leaves of Dayton barley even at $20 \mathrm{dpi}$, and we demonstrated that viral RNA was moving locally within the inoculated leaf but not systemically (Figs. 4 through 6). These data suggest that extreme resistance operates by severely inhibiting both upward and downward systemic movement of furoviruses. Resistance to systemic but not to local infection has previously been reported in several plant-virus pathosystems (Goodrick et al. 1991; Jin et al. 2006; Mahajan et al. 1998; Schaad and Carrington 1996; Wang et al. 1998). This type of resistance is thought to involve host proteins expressed within or interacting with the vasculature. Resistance to systemic infection with Tobacco etch virus (TEV) in Arabidopsis is conferred by two dominantly inherited resistance genes, RTMI (Chisholm et al. 2000; Mahajan et al. 1998) and RTM2 (Whitham et al. 1999, 2000), which are expressed specifically in phloem-associated tissues. It has been proposed that these resistance proteins may function by preventing TEV from entering the phloem (Chisholm et al. 2001). A subunit of the $26 \mathrm{~S}$ protease complex, which influences plant vascular development, was shown to be required for systemic infection by Turnip mosaic virus and Tobacco mosaic virus in Nicotiana benthamiana; whereas proteins regulating callose

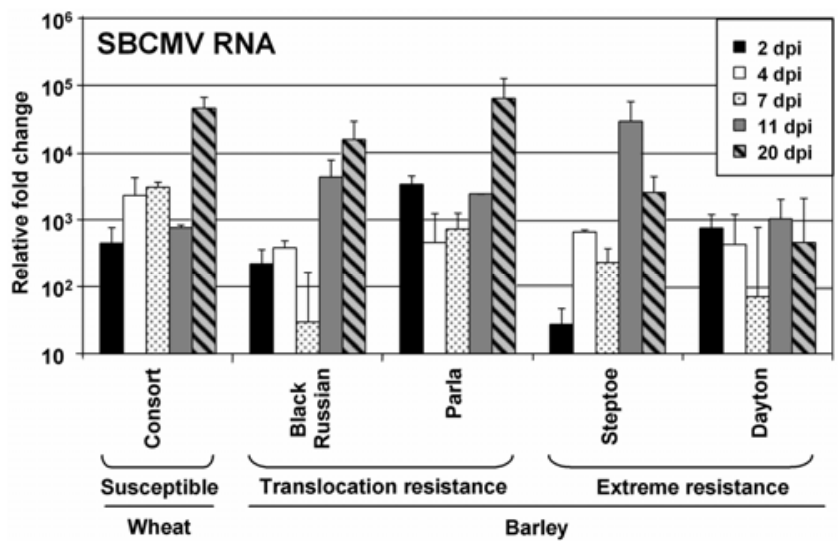

Fig. 5. Quantification of viral RNA in artificially inoculated leaves between 2 and 20 days postinoculation (dpi). Relative fold changes in the amount of Soilborne cereal mosaic virus (SBCMV) RNA detected by quantitative reverse-transcriptase polymerase chain reaction in leaves of the barley genotypes and the Consort wheat manually inoculated with SBCMV-Kent which were collected at five time points over the period from 2 to 20 dpi. 
deposition into vascular-associated plasmodesmata are involved in the systemic spread of Turnip vein clearing virus in $N$. tabacum (Ueki and Citovsky 2002, 2005). Therefore, the extreme resistance in Dayton may operate by blocking the virus entry into phloem-associated tissues, possibly due to a virus-specific or plant-genotype-specific defect in the recognition between viral movement protein and plasmodesmata, as was demonstrated for other pathosystems (Blackman et al. 1998; Wang et al. 1998). However, such a block on entry to the vasculature is yet to be demonstrated for a virus in a monocotyledonous host and, although there is evidence to suggest that phloem unloading in sink leaves is controlled symplastically (Haupt et al. 2001), the loading process in source leaves of barley is poorly understood.

RNA silencing has been shown to be activated in cells of $N$. benthamiana plants after inoculation with Potato virus $X$ or Turnip crinkle virus (Bayne et al. 2005; Ryabov et al. 2004); however, our data suggest that RNA silencing is not efficient against furoviruses in inoculated (i.e., local) tissues. In contrast, Furovirus-specific small interfering RNAs may have transported systemically ahead of the virus through the vasculature of Dayton barley, priming the distant uninoculated cells for degradation of incoming viral RNA.

Several resistant barley genotypes (i.e., Iwate Omugi 1, Barsoy, Steptoe, Aizu 6, Igri, Poland, and Golden Pheasant), which were identified in the soil inoculation tests permitted systemic infection of SBWMV but not SBCMV following manual inoculation onto the leaves. This suggests that resistance to SBCMV and SBWMV may be controlled by different resistance genes. However, the possibility that the same resistance genes control both Furovirus spp., albeit with different efficiency, cannot be excluded. Regardless, these data are additional proof that SBCMV and SBWMV possess different biological properties. At least two barley genotypes are susceptible to SBWMV from Japan (SBWMV-J) or European SBWMV isolates with identity to SBWMV-J (Hariri and Meyer 2007; Shirako and Ehara 1986). SBWMV-J shares 68 to $82 \%$ amino acid sequence identity with SBWMV-USA and 69 to $92 \%$ amino acid sequence identity with SBCMV depending on the open reading frame being sequenced (Hariri and Meyer 2007; Shirako et al. 2000). Because these polymorphisms occur throughout the genome, it is impossible to predict candidate pathogenicity factors from the viral genome sequences alone. Systematic swapping of cistrons between infectious cDNA clones of SBWMV and SBCMV would be necessary to identify the viral factor or factors contributing to virus pathogenicity on barley. However, to date, infectious cDNA clones complementary to the SBCMV RNA genome have not been produced.

One of the challenges facing Furovirus disease control is the amplification of viruliferous $P$. graminis in soil, which can remain infectious for at least a decade (Adams 1990). Barley genotypes, which display extreme resistance to furoviruses but susceptibility to $P$. graminis, could potentially be used to reduce or even eliminate the viruliferous $P$. graminis from infested soils. This possibility deserves further investigation. In addition, when the barley genes controlling extreme resistance to furoviruses are isolated, these may be useful for improving resistance in wheat via a transgenic approach or, alternatively, by a PCRbased high-throughput mining of global hexaploid wheat and diploid wheat collections (e.g., T. monococcum) for functional homologues of barley extreme resistance genes.

\section{MATERIALS AND METHODS}

\section{Biological materials.}

In all, 22 barley and 4 wheat genotypes (Supplementary Table 3) were sourced from the National Small Grains Collection, United States Department of Agriculture-Agricultural
Research Service, Aberdeen, ID, U.S.A. and the Barley Germplasm Centre, Research Institute for Bioresources, Okayama University. Soils infested with $P$. graminis and SBCMV were collected from fields in Wiltshire and Kent, U.K. (SBCMVWilt and SBCMV-Kent, respectively) as described previously (Bass et al. 2006). Soil infested with $P$. graminis and the Oklahoma isolate of SBWMV (SBWMV-Okl) was a gift from J. Verchot-Lubicz, Oklahoma State University, Stillwater, OK, U.S.A. Soils were stored dry at $4{ }^{\circ} \mathrm{C}$ in plastic boxes until use.

Natural (soil) inoculation tests and plant sample collection.

Plants of each genotype were inoculated with soils infested with SBWMV-Okl, SBCMV-Kent, or SBCMV-Wilt as described previously (Kanyuka et al. 2004) in a controlled-temperature glasshouse at $16^{\circ} \mathrm{C}$ (night) to 17 to $20^{\circ} \mathrm{C}$ (day) $\pm 2{ }^{\circ} \mathrm{C}$ with a 16-h photoperiod. Eight plants per genotype were tested
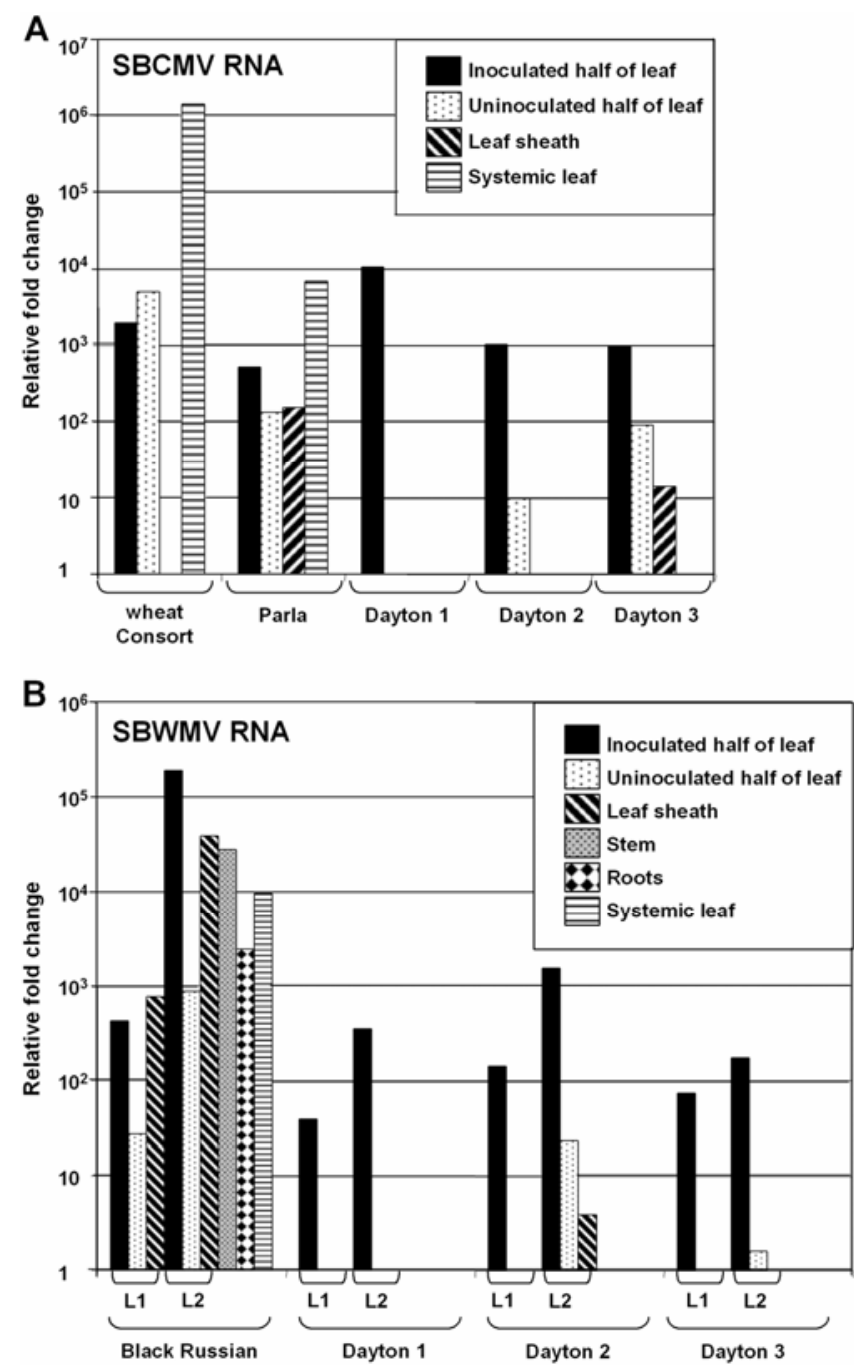

Fig. 6. Quantification of local and systemic spread of viral RNA from the primary artificially inoculated tissues. Spread of A, Soilborne cereal mosaic virus (SBCMV)-Kent RNA or B, Soilborne wheat mosaic virus (SBWMV)-Hed RNA from the point of inoculation in artificially inoculated wheat and barley genotypes at 21 days postinoculation. Relative fold changes in the amount of viral RNA detected by quantitative reverse-transcriptase polymerase chain reaction are shown for the inoculated half of the leaf, the uninoculated half and the sheath of the same leaf, the young systemic leaf, and the stem and roots (only in B). One leaf per plant was tested in A and two leaves per plant (L1 and L2) were tested in B. Leaf sheath tissue was not collected from Consort wheat. For Dayton barley, three individual plants were inoculated and tested. 
in each soil inoculation experiment and each experiment was replicated at least twice. Four plants were sown per pot and pots were placed in the glasshouse in a randomized block design. Plant leaves were harvested at two time points between 8 and 12 wpi and roots were collected at approximately $12 \mathrm{wpi}$. Samples were prepared and tested by ELISA as described previously (Kanyuka et al. 2004). The ELISA assay used is not quantitative and reported the absence or the presence of furoviral $\mathrm{CP}$ in the samples. To obtain homogeneous root samples for ELISA, RT-PCR, and PCR analyses, whole roots from each pot (containing four plants) were combined, freeze dried, ground, and then divided into three subsamples.

In all, 12 barley and 3 wheat genotypes were tested in a SBWMV-Hed-infested field near Heddesheim (SBWMV-Hed) in Baden-Württemberg, Germany (Koenig and Huth 2003) during two growing seasons (2005-06 and 2006-07). For each genotype, two rows (12 seeds per row) were sown. In April, plants at growth stage 4 on the Feekes scale (Large 1954) were visually assessed for symptoms, and the youngest fully expanded leaves were collected and tested by ELISA.

\section{Artificial virus inoculation tests and plant sample collection.}

Selected barley genotypes were manually inoculated onto their leaves with SBWMV-Hed, SBWMV-Okl, SBCMV-Kent, or SBCMV-Wilt as follows. To prepare the inocula, $1 \mathrm{~g}$ of infected Consort wheat leaves showing mosaic symptoms were finely ground in $3 \mathrm{ml}$ of inoculation buffer $\left(50 \mathrm{mM} \mathrm{H}_{2} \mathrm{KPO}_{4}\right.$, $\mathrm{pH}$ 9.2), strained through muslin, and mixed with $0.25 \mathrm{~g}$ of grade 400 Carborundum (the Carborundum Company, Manchester, U.K.). A 100- $\mu$ l aliquot of inoculum was pipetted onto the leaves of young plants at the two- to three-leaf stage and then gently rubbed between gloved thumb and forefinger. At 2 to $5 \mathrm{~min}$ postinoculation, the residual Carborundum and the inocula were washed from the inoculated leaves by spraying with tap water and the plants were transferred to the glasshouse following overnight incubation in the dark. At least eight plants were inoculated per genotype. At 4 wpi, the plants were inspected for the presence of mosaic symptoms and then systemic leaves and roots were collected and tested by ELISA. Analyses by qRT-PCR were done on systemic leaves from the same plants that were tested by ELISA. However, roots of mechanically inoculated plants were collected from separate plants for qRT-PCR and ELISA analyses. In a separate replicated experiment, primary manually inoculated leaves were collected at various time points postinoculation for conventional and qRT-PCR analyses. In a third experiment, the distal halves of the two first fully expanded leaves of wheat cv. Consort and barley cvs. Parla and Dayton, or barley cvs. Black Russian and Dayton, were inoculated with SBCMV-Kent or SBWMV-Hed, respectively. A line was then drawn on the leaves to mark the site of inoculation. At $21 \mathrm{dpi}$, the inoculated half of the leaf, the uninoculated half of the leaf $0.5 \mathrm{~cm}$ down from the line indicating the point of inoculation, the leaf sheath, and the young systemic leaf just above the point of inoculation of each plant was collected for downstream qRTPCR analyses. For SBWMV-inoculated plants, the stems and roots were also collected.

\section{TPIA.}

To determine the extent and distribution of virus infection within tissues of selected naturally and artificially inoculated barley and wheat plants, TPIA was performed as previously described (Coutts and Jones 2005) with some modifications. For each plant, cross sections of stems and leaves and a longitudinal section of the crown (i.e., stem-root junction) were pressed lightly onto a Hybond $\mathrm{C}$ nitrocellulose membrane
(Amersham Biosciences, Uppsala, Sweden). Whole roots were sandwiched between the nitrocellulose membrane and 3-mm filter paper (Whatman) and sap was transferred to the membrane by rolling over the filter paper with a heavy steel rod 250 $\mathrm{mm}$ in diameter. Placement of plant tissues was documented by scanning the membrane and tissues using a Scanjet 5470c (Hewlett Packard, Sunnyvale, CA, U.S.A.) digital scanner. Membranes were then rinsed in $2 \%$ Triton X-100 for 20 min to remove chlorophyll from the green tissues. Following $1 \mathrm{~h}$ of incubation in blocking solution $(1 \times$ phosphate-buffered saline [PBS], 5\% dry baby milk powder, and $0.1 \%$ Tween 20 ), the membranes were incubated with polyclonal SBCMV CP-specific immunoglobulin $\mathrm{G}$ antibodies $(1 \mu \mathrm{g} / \mathrm{ml}$ ) (Kanyuka et al. 2004) for $2 \mathrm{~h}$. The membranes were then rinsed two times for 10 min with $1 \times$ PBS containing $0.1 \%$ Tween 20 and incubated for $1 \mathrm{~h}$ with protein A conjugated to alkaline phosphatase (Sigma-Aldrich, St. Louis) diluted 1:2000 with 1× PBS. The membranes were then rinsed again as above and the blots were developed for $5 \mathrm{~min}$ in a substrate solution containing nitroblue tetrazolium chloride (Sigma-Aldrich) at $0.15 \mathrm{mg} / \mathrm{ml}$ and 5-bromo-4-chloro-3-indolyl phosphate (Sigma-Aldrich) at

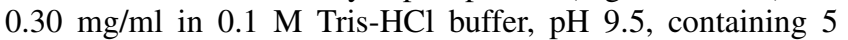
$\mathrm{mM} \mathrm{MgCl}_{2}$. The reactions were terminated by rinsing the

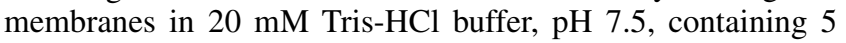
mM EDTA, pH 7.5, and the membranes were dried on blotting paper and then scanned, as above.

\section{DNA extraction and detection of $\boldsymbol{P}$. graminis ribotypes.}

To determine which $P$. graminis ribotypes were present in roots of naturally (soil) inoculated barley and wheat plants, DNA was extracted from finely ground freeze-dried roots and used as a template for amplification of $P$. graminis ribotype I and II using primers Pg.F1, Pg.R1 and Pg.F2, Pg.R1 essentially as described previously (Ward et al. 2005).

\section{Plant total RNA extraction.}

Total RNA was extracted from finely ground leaf and root samples using TRIzol reagent (Invitrogen) according to the manufacturer's instructions. Due to the presence of compounds inhibiting RT-PCR in the RNA preparations from roots of plants grown in SBCMV-Wilt-infested soil, the RNA from selected samples was reextracted using the RNeasy plant mini kit (Qiagen, Basel, Switzerland) according to the manufacturer's manual. RNA concentration and quality were assessed spectrophotometrically using the Nanodrop ND-1000 (NanoDrop Technologies, Wilmington, DE, U.S.A.) and by denaturing gel electrophoresis.

\section{Detection of SBCMV and SBWMV RNA using conventional RT-PCR.}

RT-PCR was carried out on total RNA extracted from roots or shoots of soil-inoculated barley plants. Total RNA $(1 \mu \mathrm{g})$ was primed with oligo(dT) $)_{15}$ (Promega, Madison, WI, U.S.A.) and converted to the first-strand cDNA using Superscript III (Invitrogen) according to the manufacturer's instructions. The template RNA was digested with $1.5 \mathrm{U}$ of RNase $\mathrm{H}$ (Promega or New England Biolabs) at $37^{\circ} \mathrm{C}$ for $20 \mathrm{~min}$. Subsequent 25 $\mu \mathrm{l}$ PCR reactions contained $2 \mu \mathrm{l}$ of first-strand cDNA, $1 \times$ PCR buffer, $0.4 \mathrm{mM}$ dNTPs, $3 \mathrm{mM} \mathrm{MgCl}$, $2 \mathrm{U}$ of Taq DNA Polymerase (Invitrogen), and $0.4 \mu \mathrm{M}$ of each SBWMV-UNIF and SBWMV-UNIR primer (Clover et al. 2001). Cycling conditions were $2 \mathrm{~min}$ at $95^{\circ} \mathrm{C}$; then 35 cycles of $30 \mathrm{~s}$ at $95^{\circ} \mathrm{C}, 30 \mathrm{~s}$ at $60^{\circ} \mathrm{C}$, and $45 \mathrm{~s}$ at $72^{\circ} \mathrm{C}$; followed by $5 \mathrm{~min}$ at $72^{\circ} \mathrm{C}$. In all conventional RT-PCR analyses, amplification of a plant gene, the partial eIF4E open reading frame, using RESK-99 and RESK-102 primers (Kanyuka et al. 2005) was used to confirm cDNA quality and integrity. 


\section{qRT-PCR for analyses of relative fold changes in the amount of viral RNA.}

RT-PCR was carried out on total RNA extracted from roots or the aerial parts of test plants. Prior to the first-strand cDNA synthesis, contaminating genomic DNA was removed from total RNA preparations using the TURBO DNA-free kit (Ambion. Austin, TX, U.S.A.). First-strand cDNA synthesis was conducted as described above. Primer pairs were designed to amplify 71-bp amplicons specifically from SBCMV, SBWMV, and the plant housekeeping gene, eIF4E (Table 2), using Primer Express software (Applied Biosystems, Foster City, CA, U.S.A.). PCR reactions were carried out in 96-well plates with the PRISM 7700 Sequence Detection System (Applied Biosystems) using SYBR green to monitor doubled-stranded DNA synthesis. Each $25-\mu \mathrm{l}$ qRT-PCR reaction contained $0.4 \mu \mathrm{l}$ of first-strand cDNA, $1 \mathrm{mM} \mathrm{MgCl}_{2}, 1 \times \mathrm{SYBR}$ green master mix, $10 \mathrm{nM}$ ROX Reference dye (VH Bio), and $0.3 \mu \mathrm{M}$ each primer. The cycling parameters were $10 \mathrm{~min}$ at $95^{\circ} \mathrm{C}$ followed by 35 cycles of $15 \mathrm{~s}$ at $95^{\circ} \mathrm{C}, 30 \mathrm{~s}$ at $60^{\circ} \mathrm{C}$, and $1 \mathrm{~min}$ at $72^{\circ} \mathrm{C}$. Reactions for each primer pair were performed in triplicate. $\mathrm{Ct}$ values were obtained using the ABI PRISM Sequence Detector software (version 1.2.1; Applied Biosystems). To determine the reaction efficiency of the primer pairs, cDNA samples were pooled and primer pairs were used to amplify serial dilutions of the template mixes to generate a standard curve from which the reaction efficiency (E) was calculated as described previously (Table 2) (Rasmussen 2001). Normalized expression values (NE) were then calculated using the equation: $\mathrm{NE}=$ $\mathrm{E}^{(-\mathrm{Ct} \text { (virus)) }} / \mathrm{E}-{ }^{(-\mathrm{Ct}(\mathrm{eIF} 4 \mathrm{E}))}$ (Pfaffl 2001). The mean of the triplicate eIF4E Ct values were subtracted from each of the three individual $\mathrm{Ct}$ values and the mean $\mathrm{NE}$ and standard error were then calculated for each sample. NE values for all samples were then calculated relative to a calibrator sample. The calibrator samples were those which contained the lowest $\mathrm{NE}$ value for each set of virus primers. For SBCMV-Wilt, the calibrator sample was the systemic leaf of a Dayton barley plant collected at 4 weeks post-artificial inoculation. For SBWMV$\mathrm{Okl}$, the calibrator sample was the soil-inoculated roots of barley cv. Ellis. Specificity of the primers was confirmed using dissociation curve analysis and gel electrophoresis for each reaction.

\section{ACKNOWLEDGMENTS}

We thank W. Huth, R. Goetz, and K. Rohst (Federal Biological Research Centre for Agriculture and Forestry, Braunschweig, Germany) for setting up and managing the trials in the SBWMV-infested field near Heddesheim, Germany, and for the collection of plant samples in 2007; and N. D. K. Yilmaz (Ondokuz Mayis University, Samsun, Turkey) for helping to establish the TPIA in our laboratory. Rothamsted Research receives grantaided support from the Biotechnology and Biological Sciences Research Council (BBSRC) of the United Kingdom. R. Lyons was supported by a BBSRC quota studentship awarded to Rothamsted Research.

\section{LITERATURE CITED}

Adams, M. J. 1990. Epidemiology of fungally transmitted viruses. Soil Use Manage. 6:184-189.

Adams, M. J., and Jacquier, C. 1994. Infection of cereals and grasses by isolates of Polymyxa graminis (Plasmodiophorales). Ann. Appl. Biol. 125:53-60.

Barbosa, M. M., Goulart, L. R., Prestes, A. M., and Juliatti, F. C. 2001. Genetic control of resistance to Soilborne wheat mosaic virus in Brazilian cultivars of Triticum aestivum L. Thell. Euphytica 122:417-422.

Bass, C., Hendley, R., Hammond-Kosack, K., and Kanyuka, K. 2006. The Sbml locus conferring resistance to Soilborne cereal mosaic virus maps to a gene-rich region of 5DL in wheat. Genome 49:1140-1148.

Bayne, E. H., Rakitina, D. V., Morozov, S. Y., and Baulcombe, D. C. 2005. Cell-to-cell movement of potato potexvirus $\mathrm{X}$ is dependent on suppression of RNA silencing. Plant J. 44:471-482.
Blackman, L. M., Boevink, P., Cruz, S. S., Palukaitis, P., and Oparka, K. J. 1998. The movement protein of Cucumber mosaic virus traffics into sieve elements in minor veins of Nicotiana clevelandii. Plant Cell 10:525-537.

Brakke, M. K.1971. Soilborne wheat mosaic virus. No. 77 in: Descriptions of Plant Viruses. Commonwealth Mycological Institute/Association of Applied Biologists, Kew, England.

Brakke, M. K., and Landenberg, W. 1988. Experiences with Soilborne wheat mosaic virus in North America and elsewhere. Dev. Appl. Biol. 2:183-202.

Cadle-Davidson, L., Sorrells, M. E., Gray, S. M., and Bergstrom, G. C. 2006. Identification of small grains genotypes resistant to Soilborne wheat mosaic virus. Plant Dis. 90:1039-1044.

Chisholm, S. T., Mahajan, S. K., Whitham, S. A., Yamamoto, M. L., and Carrington, J. C. 2000. Cloning of the Arabidopsis RTM1 gene, which controls restriction of long-distance movement of Tobacco etch virus. Proc. Natl. Acad. Sci. U.S.A. 97:489-494.

Chisholm, S. T., Parra, M. A., Anderberg, R. J., and Carrington, J. C. 2001 Arabidopsis RTM1 and RTM2 genes function in phloem to restrict longdistance movement of Tobacco etch virus. Plant Physiol. 127:16671675 .

Clover, G. R. G., Wright, D. M., and Henry, C. M. 1999. First report of Soilborne wheat mosaic virus in the United Kingdom. Plant Dis. 83:880.

Clover, G. R. G., Ratti, C., and Henry, C. M. 2001. Molecular characterization and detection of European isolates of Soilborne wheat mosaic virus. Plant Pathol. 50:761-767.

Coutts, B. A., and Jones, R. A. C. 2005. Incidence and distribution of viruses infecting cucurbit crops in the Northern Territory and Western Australia. Aust. J. Agric. Res. 56:847-858.

Diao, A. P., Chen, J. P., Gitton, F., Antoniw, J. F., Mullins, J., Hall, A. M., and Adams, M. J. 1999. Sequences of European wheat mosaic virus and Oat golden stripe virus and genome analysis of the genus Furovirus. Virology 261:331-339.

Driskel, B. A., Hunger, R. M., Payton, M. E., and Verchot-Lubicz, J. 2002. Response of hard red winter wheat to Soilborne wheat mosaic virus using novel inoculation methods. Phytopathology 92:347-354.

Gill, G. 2004. Mosaic virus detected in Canterbury wheat field. Biosecur. 54:17.

Goodrick, B. J., Kuhn, C. W., and Hussey, R. S. 1991. Restricted systemic movement of Cowpea chlorotic mottle virus in soybean with nonnecrotic resistance. Phytopathology 81:1426-1431.

Hariri, J., and Meyer, M. 2007. A new Furovirus infecting barley in France closely related to the Japanese Soilborne wheat mosaic virus. Eur. J. Plant Pathol. 118:1-10.

Haupt, S., Duncan, G. H., Holzberg, S., and Oparka, K. J. 2001. Evidence for symplastic phloem unloading in sink leaves of barley. Plant Physiol. 125:209-218.

Hou, M., Han, H., Zhou, Y., and Xiao, Q. 1985. Studies on a soilborne virus disease of wheat in Jiangsu province: Rules governing the incidence of the disease and identification of the pathogen. Jiangsu J. Agric. Sci. $1: 25-28$.

Hunger, R. M., Armitage, C. R., and Sherwood, J. L. 1989. Effects of wheat soilborne mosaic virus on hard red winter wheat. Plant Dis. 73:949-952.

Huth, W., Gotz, R., and Lesemann, D. E. 2007. Different types of resistance to soilborne viruses of wheat. Gesunde Pflanz. 59:29-39.

Jezewska, M. 1995. Detection of Polish isolate of Wheat soilborne mosaic virus in cereal seeds. Phytopathol. Pol. 10:61-67.

Jin, H. L., Li, S. T., and Villegas, A. 2006. Down-regulation of the $26 \mathrm{~S}$ proteasome subunit RPN9 inhibits viral systemic transport and alters plant vascular development. Plant Physiol. 142:651-661.

Kanyuka, K., Ward, E., and Adams, M. J. 2003. Polymyxa graminis and the cereal viruses it transmits: A research challenge. Mol. Plant Pathol. 4:393-406.

Kanyuka, K., Lovell, D. J., Mitrofanova, O. P., Hammond-Kosack, K., and Adams, M. J. 2004. A controlled environment test for resistance to Soilborne cereal mosaic virus (SBCMV) and its use to determine the mode of inheritance of resistance in wheat cv. Cadenza and for screening Triticum monococcum genotypes for sources of SBCMV resistance. Plant Pathol. 53:154-160.

Kanyuka, K., Druka, A., Caldwell, D. G., Tymon, A., McCallum, N., Waugh, R., and Adams, M. J. 2005. Evidence that the recessive bymovirus resistance locus rym4 in barley corresponds to the eukaryotic translation initiation factor $4 E$ gene. Mol. Plant Pathol. 6:449-458.

Kapooria, R. G., Ndunguru, J., and Clover, G. R. G. 2000. First reports of Soilborne wheat mosaic virus and Wheat spindle streak mosaic virus in Africa. Plant Dis. 84:921.

Kastirr, U., Wortmann, H., and Ehrig, F. 2006. Untersuchungen zum Infektionsverlauf und zur biologischen Differenzierung von bodenbürtigen 
Viren in Roggen, Triticale und Weizen. Gesunde Pflanz. 58:231-238.

Koenig, R., and Huth, W. 2000a. Nucleotide sequence analyses indicate that a furo-like virus from cereal, formerly considered to be a strain of Soilborne wheat mosaic virus, should be regarded as a new virus species: Soilborne cereal mosaic virus. Z. Pflanzenkrankh. Pflanzenschutz 107:445-446.

Koenig, R., and Huth, W. 2000b. Soilborne rye mosaic and European wheat mosaic virus: Two names for a furovirus with variable genome properties which is widely distributed in several cereal crops in Europe. Arch. Virol. 145:689-697.

Koenig, R., and Huth, W. 2003. Natural infection of wheat by the type strain of Soilborne wheat mosaic virus in a field in Southern Germany. Eur. J. Plant Pathol. 109:191-193.

Koenig, R., Pleij, C. W. A., and Huth, W. 1999. Molecular characterization of a new furovirus mainly infecting rye. Arch. Virol. 144:2125-2140.

Large, E. C. 1954. Growth stages in cereals-illustration of the Feekes scale. Plant Pathol. 3:128-129.

Mahajan, S. K., Chisholm, S. T., Whitham, S. A., and Carrington, J. C. 1998. Identification and characterization of a locus (RTMI) that restricts long-distance movement of Tobacco etch virus in Arabidopsis thaliana. Plant J. 14:177-186.

McKinney, H. H. 1930. A mosaic of wheat transmissible to all cereal species in the tribe Hordeae. J. Agric. Res. 40:547-556.

McKinney, H. H. 1937. Mosaic disease of wheat and related cereals. U. S. Dep. Agric. Circ. 442:23.

McKinney, H. H. 1948. Wheats immune from soilborne mosaic viruses in the field, susceptible when inoculated manually. Phytopathology 38:1003-1013.

Modawi, R. S., Heyne, E. G., Brunetta, D., and Willis, W. G. 1982. Genetic studies of field reaction to wheat soilborne mosaic virus. Plant Dis. 66:1183-1184

Myers, L. D., Sherwood, J. L., Siegerist, W. C., and Hunger, R. M. 1993. Temperature-influenced virus movement in expression of resistance to Soilborne wheat mosaic virus in hard red winter wheat (Triticum aestivum). Phytopathology 83:548-551.

Pfaffl, M. W. 2001. A new mathematical model for relative quantification in real-time RT-PCR. Nucleic Acids Res. 29:e45.

Rao, A. S., and Brakke, M. K. 1969. Relation of Soilborne wheat mosaic virus and its fungal vector Polymyxa graminis. Phytopathology 59:581587.

Rasmussen, R. 2001. Quantification on the light cycler. Pages 21-34 in: Rapid cycle real-time PCR, methods and applications. S. Meuer, C. Wittwer, and K. Nakagawara, eds. Springer Press, Heidelberg.

Ratti, C., Budge, G., Ward, L., Clover, G., Rubies-Autonell, C., and Henry, C. 2004. Detection and relative quantification of Soilborne cereal mosaic virus (SBCMV) and Polymyxa graminis in winter wheat using real-time PCR (TaqMan®). J. Virol. Methods 122:95-103.

Ryabov, E. V., van Wezel, R., Walsh, J., and Hong, Y. 2004. Cell-to-cell, but not long-distance, spread of RNA silencing that is induced in individual epidermal cells. J. Virol. 78:3149-3154

Schaad, M. C., and Carrington, J. C. 1996. Suppression of long-distance movement of Tobacco etch virus in a nonsusceptible host. J. Virol. 70:2556-2561.
Shirako, Y., and Ehara, Y. 1986. Comparison of the in vitro translation products of wild-type and a deletion mutant of Soilborne wheat mosaic virus. J. Gen. Virol. 67:1237-1245.

Shirako, Y., Suzuki, N., and French, R. C. 2000. Similarity and divergence among viruses in the genus Furovirus. Virology 270:201-207.

Torrance, L., and Koenig, R. 2005. Genus Furovirus. Pages 1025-1030 in: Virus Taxonomy, 2nd ed. VIIIth Rep. Int. Committee on Taxonomy of Viruses. C. M. Fauquet, M. A. Mayo, J. Maniloff, U. Desselberger, and L. A. Ball, eds. Elsevier Academic Press, London.

Ueki, S., and Citovsky, V. 2002. The systemic movement of a tobamovirus is inhibited by a cadmium-ion-induced glycine-rich protein. Nat. Cell Biol. 4:478-485.

Ueki, S., and Citovsky, V. 2005. Identification of an interactor of cadmium ion-induced glycine-rich protein involved in regulation of callose levels in plant vasculature. Proc. Natl. Acad. Sci. U.S.A. 102:12089-12094.

Vaianopoulos, C., Bragard, C., Moreau, V., Maraite, H., and Legreve, A 2007. Identification and quantification of Polymyxa graminis f. sp. temperata and $P$. graminis f. sp. tepida on barley and wheat. Plant Dis. 91:857-864.

Vallega, V., Rubies-Autonell, C., Turina, M., Ratti, C., and Contoli, S. 1999. Reactions of durum wheat cultivars to infections by Soilborne wheat mosaic virus grown in northern Italy during 1995-96. Z. Pflanzenkrankh. Pflanzenschutz. 106:284-290.

Verchot, J., Driskel, B. A., Zhu, Y., Hunger, R. M., and Littlefield, L. J. 2001. Evidence that Soilborne wheat mosaic virus moves long distance through the xylem in wheat. Protoplasma 218:57-66.

Wang, H. L., Wang, Y., Giesman-Cookmeyer, D., Lommel, S. A., and Lucas, W. J. 1998. Mutations in viral movement protein alter systemic infection and identify an intercellular barrier to entry into the phloem long-distance transport system. Virology 245:75-89.

Ward, E., Adams, M. J., Mutasa, E. S., Collier, C. R., and Asher, M. J. C. 1994. Characterization of Polymyxa species by restriction analysis of PCR amplified ribosomal DNA. Plant Pathol. 43:872-877.

Ward, E., Kanyuka, K., Motteram, J., Kornyukhin, D., and Adams, M. J. 2005. The use of conventional and quantitative real-time PCR assays for Polymyxa graminis to examine host plant resistance, inoculum levels and intraspecific variation. New Phytol. 165:875-885.

Whitham, S. A., Yamamoto, M. L., and Carrington, J. C. 1999. Selectable viruses and altered susceptibility mutants in Arabidopsis thaliana. Proc. Natl. Acad. Sci. U.S.A. 96:772-777.

Whitham, S. A., Anderberg, R. J., Chisholm, S. T., and Carrington, J. C. 2000. Arabidopsis RTM2 gene is necessary for specific restriction of Tobacco etch virus and encodes an unusual small heat shock-like protein. Plant Cell 12:569-582.

\section{AUTHOR-RECOMMENDED INTERNET RESOURCES}

Descriptions of Plant Viruses website: www.dpvweb.net

Germplasm Resources Information Network (GRIN) website: www.arsgrin.gov

The International Working Group On Plant Viruses With Fungal Vectors (IWGPVFV) website: www.rothamsted.bbsrc.ac.uk/ppi/Iwgpvfv 